\title{
Crossed aphasia. II: Why are deep lesions overrepresented with respect to standard aphasia?
}

\author{
M. Laiacona ${ }^{1}$, E. Capitani ${ }^{2}$, C. Stangalino ${ }^{1}$ and L. Lorenzi ${ }^{1}$ \\ ${ }^{1}$ Neuropsychology Unit, Neurology Department, Salvatore Maugeri Clinica del Lavoro \\ Foundation, Medical Centre of Rehabilitation, Veruno (NO) and ${ }^{2}$ Milan University, Clinic for \\ Nervous Diseases, S. Paolo Hospital, Milan, Italy
}

Correspondence to: Dr M. Laiacona, Servizio di Neuropsicologia della Fondazione S. Maugeri Clinica del Lavoro, Istituto di Ricovero e Cura a Carattere Scientifico, Centro Medico di Riabilitazione di Veruno (NO), Italy

\begin{abstract}
In this paper we have reviewed the cases of vascular crossed aphasia reported in the literature, in order to check whether deep lesions are really overrepresented in crossed aphasia with respect to standard aphasia. The comparison with a large sample of standard left-hemisphere-damaged aphasics revealed a significantly higher incidence of purely deep lesions in crossed aphasics than in standard aphasics. The overrepresentation of deep lesions in crossed aphasia appears to be contingent on the co-occurrence of aphasia and Unilateral Neglect after right-hemisphere lesion. This suggests an interaction between language and attentional mechanisms in the case of reversed language lateralisation: the overcrowding of these functions in the right hemisphere could make language more vulnerable after right deep lesions.
\end{abstract}

Keywords: Aphasia - Deep lesions - Hemispheric specialisation

\section{INTRODUCTION}

The aim of this paper was to review the cases of crossed aphasics reported in the literature, in order to see whether there is really an overrepresentation of deep lesions, as suggested by Habib et al. (1983). We first took into account the hypothesis of Habib and colleagues concerning the special role of deep nuclei in crossed aphasia attributable to their possible lesser degree of lateralisation. Following a different approach, we then discuss whether the distribution of lesions in crossed aphasics is influenced by the crowding of language and spatial abilities within the same hemisphere.

\section{METHODS AND RESULTS}

Review of the published cases of deep crossed aphasia

We will start by updating the review of crossed aphasic patients published by Joanette et al. (1982), following the strict criteria adopted by those authors that are listed below.

(1) Strong right-handedness with no familial (parents and siblings) sinistrality.
(2) Literacy.

(3) Unilingual.

(4) Absence of childhood brain damage or previous lesions in adulthood.

(5) CT-documented lesion restricted to the right hemisphere.

(6) Thorough language testing at least two weeks post-onset of the disease.

We excluded cases of head injury, neoplasia and infections of the central nervous system because, as pointed out by Boller (1973), such lesions might cause bilateral damage. Considering only deep lesions, eight patients in the literature, and the patient MR (see accompanying paper) fulfilled these criteria. Tables $1 \mathrm{~A}$ and $1 \mathrm{~B}$ show the clinical data of the nine patients considered.

In these cases, testing most frequently disclosed the association of a 'left-hemisphere' deficit (aphasia and acalculia) and unilateral neglect (which is generally associated with right-hemisphere lesions). No consistent aphasic pattern was evident apart from the greater impairment of written language and the better preserved repetition described in most "subcortical" cases. 
TABLE IA. Clinical data and neuropsychological features of deep crossed aphasics

\begin{tabular}{|c|c|c|c|c|c|c|c|c|c|c|c|c|c|c|c|}
\hline Case & $\begin{array}{l}\text { Age } \\
\text { (years) }\end{array}$ & Sex & M.D. & S.D. & $\begin{array}{c}\text { Type } \\
\text { of lesion }\end{array}$ & $\begin{array}{l}\text { Side of lesion } \\
\text { lesion }\end{array}$ & $\begin{array}{l}\text { Type of } \\
\text { asphasia }\end{array}$ & $\begin{array}{l}\text { O/W } \\
\text { diss. }\end{array}$ & $\begin{array}{l}\text { L-H fL } \\
\text { IMA }\end{array}$ & $\begin{array}{c}\text { uncti } \\
\text { OA }\end{array}$ & AC & $\begin{array}{l}\text { Bilateral } \\
\text { CAP }\end{array}$ & $\begin{array}{l}\text { R-H f } \\
\text { ULN }\end{array}$ & $\begin{array}{l}\text { functi } \\
\text { S-P }\end{array}$ & $\begin{aligned} \text { ions } \\
\text { AL }\end{aligned}$ \\
\hline $\begin{array}{l}1 \\
\text { MR }\end{array}$ & 67 & $M$ & + & + & $\mathrm{H}$ & $\begin{array}{l}\text { Thalamus, } \\
\text { putamen }\end{array}$ & Broca & $w<0$ & - & - & + & - & + & - & + \\
\hline $\begin{array}{l}2 \\
\text { Carr et al. } \\
\text { (1981) } \\
\text { case No } 3\end{array}$ & 80 & $M$ & + & - & $\mathrm{H}$ & $\begin{array}{l}\text { Deep temporal, } \\
\text { internal capsule, } \\
\text { thalamus, caudate } \\
\text { nucleus, putamen }\end{array}$ & Tr. s. & $w<0$ & ne & ne & ne & ne & + & ne & - \\
\hline $\begin{array}{l}3 \\
\text { Habib et al } \\
\text { (1983) }\end{array}$ & 61 & M & + & + & 1 & $\begin{array}{l}\text { Lenticular nucleus, } \\
\text { caudate nucleus, } \\
\text { internal capsule }\end{array}$ & W. & $w<0$ & ne & ne & ne & + & + & ne & ne \\
\hline $\begin{array}{l}4 \\
\text { Colombo } \\
\text { et al. }(1984)\end{array}$ & $\begin{array}{l}67 \\
4)\end{array}$ & M & + & + & $\mathrm{H}$ & Basal ganglia & W. & $w<0$ & - & - & ne & + & + & ne & ne \\
\hline $\begin{array}{l}5 \\
\text { Basso et al. } \\
\text { (1985) case } \\
\text { No } 6\end{array}$ & $e^{56}$ & $M$ & + & + & $\mathrm{H}$ & $\begin{array}{l}\text { Basal ganglia, } \\
\text { insula, internal } \\
\text { and external } \\
\text { capsule }\end{array}$ & W. & $w<0$ & - & - & + & - & $\mathrm{pp}-$ & ne & ne \\
\hline $\begin{array}{l}6 \\
\text { Fromm } \\
\text { et al. (1985) } \\
\text { case No } 6\end{array}$ & 64 & $M$ & + & ne & $\mathrm{H}$ & $\begin{array}{l}\text { Lenticular nucleus, } \\
\text { internal capsule }\end{array}$ & Tr.s. & $w<0$ & ne & ne & ne & + & + & ne & ne \\
\hline $\begin{array}{l}7 \\
\text { Fromm } \\
\text { et al. }(1985) \\
\text { case No } 11\end{array}$ & $\begin{array}{l}75 \\
5) \\
1\end{array}$ & $M$ & + & + & $\mathrm{H}$ & Thalamus & A. & $w<0$ & ne & ne & + & ne & + & ne & ne \\
\hline $\begin{array}{l}8 \\
\text { Perani } \\
\text { et al. (1988) } \\
\text { case No } 2\end{array}$ & 67 & M & + & - & $\mathrm{H}$ & $\begin{array}{l}\text { Basal ganglia, } \\
\text { internal capsule, } \\
\text { thalamus }\end{array}$ & Tr. Mix. & $w<0$ & + & + & ne & + & - & ne & ne \\
\hline $\begin{array}{l}9 \\
\text { Cappa } \\
\text { et al. (1993) } \\
\text { case No } 1\end{array}$ & 79 & $F$ & + & + & 1 & $\begin{array}{l}\text { Lenticular nucleus, } \\
\text { periventricular } \\
\text { white matter }\end{array}$ & Tr. Mix. & $w<0$ & + & + & ne & $\mathrm{Ne}$ & + & ne & ne \\
\hline
\end{tabular}

Motor Deficits (M.D., + presence/- absence), Sensory Deficits (S.D., + presence/- absence), Haemorrhage (H), Ischaemia (I), OM diss. $=$ oral tasks are performed better $(>)$, equal to $(=)$ or worse $(<)$ than written tasks at least in one instance. Broca Aphasia (B), Transcortical Sensitive Aphasia (Tr.s), Wernicke Aphasia (W), Conduction Aphasia (C), Mixed Transcortical Aphasia (Tr.mix.) Amnestic Aphasia (A.); Left hemisphere (L-H), Right hemisphere (R-H), Ideomotor Apraxia (IMA), Oral Apraxia (OA), Constructional Apraxia (CAP), Acalculia (AC), Unilateral Neglect (ULN), Spatial and Perceptual Impairment (S-P), Affective Language (AL), Pathological (+), Normal (-), Not Examined (ne), Position Preference (pp).

TABLE IB. Language patterns of deep crossed aphasics

\begin{tabular}{|c|c|c|c|c|}
\hline Case & Speech output & Comprehension & Repetition & Writing \\
\hline 1 & $\begin{array}{l}\text { Paucity of speech, echolalia, } \\
\text { wordfinding difficulties, verbal } \\
\text { paraphasias, non-words }\end{array}$ & Mild & Mild & $\begin{array}{l}\text { Mispelt, unrecognisable } \\
\text { words }\end{array}$ \\
\hline 2 & $\begin{array}{l}\text { Echolalia, jargon, verbal and literal } \\
\text { paraphasia, non-words }\end{array}$ & Poor & Mild & Strings of unrelated words \\
\hline $\begin{array}{l}3 \\
4\end{array}$ & $\begin{array}{l}\text { Phonemic and verbal paraphasias, jargon } \\
\text { Dysarthrias, word-finding difficulties, } \\
\text { verbal paraphasias, non-words }\end{array}$ & $\begin{array}{l}\text { Good } \\
\text { Poor }\end{array}$ & $\begin{array}{l}\text { Mild } \\
\text { Poor }\end{array}$ & $\begin{array}{l}\text { Pure jargon } \\
\text { Unrecognisable words }\end{array}$ \\
\hline 5 & $\begin{array}{l}\text { Poor, word-finding difficulties, } \\
\text { phonemic paraphasias }\end{array}$ & Good & Normal & Unrecognisable words \\
\hline $\begin{array}{l}6 \\
7\end{array}$ & $\begin{array}{l}\text { Paraphasias, anomias, perseverations } \\
\text { Anomias }\end{array}$ & $\begin{array}{l}\text { Impaired } \\
\text { Mild }\end{array}$ & $\begin{array}{l}\text { Excellent } \\
\text { Mild }\end{array}$ & $\begin{array}{l}\text { Impaired } \\
\text { Sloppy, inaccurate or } \\
\text { imcomplete }\end{array}$ \\
\hline $\begin{array}{l}8 \\
9\end{array}$ & $\begin{array}{l}\text { Poor, jargon, semantic paraphasias } \\
\text { Severe reduction, anomias, } \\
\text { paraphasias, perseverations }\end{array}$ & $\begin{array}{l}\text { Severely affected } \\
\text { Defective }\end{array}$ & $\begin{array}{l}\text { Mild } \\
\text { Mild }\end{array}$ & $\begin{array}{l}\text { Only his signature } \\
\text { Severe agraphia }\end{array}$ \\
\hline
\end{tabular}

164 Behavioural Neurology • Vol 9 . 1996 


\section{The role of deep structures in crossed aphasia}

Habib et al. (1983) have suggested that the deep nuclei play a major role in the genesis of crossed aphasia because of their lesser lateralisation. Seemingly, this implies that deep lesions are more common among crossed aphasics than standard aphasics. A greater prevalence of subcortical lesions in crossed aphasia has already been remarked upon (Joanette et al., 1982; Cappa et al., 1993) and questioned (Basso et al., 1985), but never confirmed in a population study. Thus, to test this hypothesis, we compared the incidence of deep lesions in crossed and standard aphasics. In addition to the cases reviewed by Joanette et al. (1982), we found further reports of crossed aphasia which met Joanette et al.'s criteria listed above. Table II shows the cases reported by Joanette et al. (1982), and the new cases (until May 1994). Thirty-six patients (including MR, see accompanying paper) fulfilled our adopted criteria. The excluded cases and the grounds for their exclusion are reported in the Appendix.

TABLE II. Reported cases of crossed aphasia

\begin{tabular}{|c|c|c|c|c|c|c|c|c|c|}
\hline & & Age & Sex & Aphasia & ULN & $\mathrm{C}, \mathrm{WM}$ & DWM & $\mathrm{C}+\mathrm{DN}$ & DN \\
\hline 1) & Urbain et al. 1978 & 37 & $\mathrm{~F}$ & B & - & + & & & \\
\hline 2) & Denes and Caviezel, 1981 & 35 & M & B & - & & & + & \\
\hline 3) & Carr et al. 1981, No2 & 61 & $M$ & G & - & + & & & \\
\hline 4) & Carr et al. 1981, No3 & 80 & M & TS & + & & & & + \\
\hline 5) & Haaland and Miranda, 1983 & 67 & $\mathrm{~F}$ & C & - & & + & & \\
\hline 6) & Puel et al. 1982 & 55 & $M$ & $\mathrm{C}$ & + & & & + & \\
\hline 7) & Assal, 1982 & 60 & $M$ & C & - & & & + & \\
\hline 8) & Habib et al. 1983 & 61 & $M$ & $\mathrm{C}$ & + & & & & + \\
\hline 9) & Henderson, 1983, No2 & 60 & $F$ & W & + & + & & & \\
\hline 10) & Henderson, 1983, No3 & 61 & M & W & + & + & & & \\
\hline 11) & Colombo et al. 1984 & 67 & $M$ & W & + & & & & + \\
\hline 12) & Kapur and Dunkley, 1984 & 57 & $M$ & B & + & & & + & \\
\hline 13) & Hindson et al. 1984 & 72 & M & B & - & + & & & \\
\hline 14) & Basso et al. 1985, No1 & 64 & $F$ & B & - & + & & & \\
\hline 15) & Basso et al. 1985, No2 & 53 & $\mathrm{~F}$ & W & + & + & & & \\
\hline 16) & Basso et al. 1985, No3 & 55 & M & W & + & + & & & \\
\hline 17) & Basso et al. 1985, No4 & 63 & $F$ & W & - & + & & & \\
\hline 18) & Basso et al. 1985, No5 & 49 & $\mathrm{~F}$ & $A G$ & + & + & & & \\
\hline 19) & Basso et al. 1985, No6 & 56 & M & W & - & & & & + \\
\hline 20) & Basso et al. 1985, No7 & 64 & $\mathrm{~F}$ & B & + & + & & & \\
\hline 21) & Fromm et al. 1985 No6 & 64 & $M$ & TS & + & & & & + \\
\hline 22) & Fromm et al. 1985, No11 & 75 & M & $A$ & + & & & & + \\
\hline 23) & Demeurisse et al. 1986 & 65 & $M$ & W & - & & & + & \\
\hline 24) & Reinvang, 1987 & 56 & M & TS & + & & & + & \\
\hline 25) & Schweiger et al. 1987 & 59 & M & $\mathrm{FL}$ & - & + & & & \\
\hline 26) & Castro-Caldas et al. 1987, N1 & 34 & M & B & - & + & & & \\
\hline 27) & Castro-Caldas et al. 1987, N2 & 66 & M & G & + & + & & & \\
\hline 28) & Perani et al. 1988, No2 & 67 & M & TMx & - & & & & + \\
\hline 29) & Delreux et al. 1989 & 74 & M & B & - & + & & & \\
\hline 30) & Alexander et al. 1989, No1 & 54 & $M$ & W & - & & & + & \\
\hline 31) & Faglia and Vignolo, 1990 & 65 & $\mathrm{~F}$ & G & + & & & + & \\
\hline 32) & Berndt et al. 1991 & 56 & $\mathrm{~F}$ & C & - & + & & & \\
\hline 33) & Cappa et al. 1993, No1 & 79 & $\mathrm{~F}$ & $\mathrm{TMx}$ & + & & & & + \\
\hline 34) & Cappa et al. 1993 No2 & 56 & M & FL & - & & + & & \\
\hline 35) & Cohen et al. 1993 & 72 & $F$ & B & - & + & & & \\
\hline 36) & MR & 67 & M & B & + & & & & + \\
\hline
\end{tabular}

Cortical lesion (with or without participation of the immediately underlying white matter) (C,WM), Deep white matter lesion in a specific lobe (DWM), Cortical and deep nuclei lesion (C+DN), Deep nuclei lesion (DN), Global aphasia (G), Broca's aphasia (B), Conduction aphasia (C), Wernicke's aphasia (W), Transcortical Sensitive aphasia (TS), Agraphia (AG), Transcortical Mixed aphasia (TMx), Fluent aphasia (FL); Unilateral Neglect (ULN); position preference ( $p p+)$. Patients have been classified as ULN + if they had definite Neglect or position preference not accounted for by hemianopia. 
We considered a reference sample of 287 standard aphasic patients from Milan University (Laiacona, 1985) who met the criteria used in our list of crossed aphasics. This sample was drawn from a continuous series of 1085 patients tested in the Aphasia Unit of the University of Milan (Neurological Department), in the period 1978-1985 and was studied (courtesy of Prof. A Basso) by one of the authors (M.L.) in her post-doctoral dissertation (Laiacona, 1985). Part of these patients were also studied in the paper by Basso, et al. (1987). In the reference sample, all patients had focal left hemisphere damage whose vascular aetiology and site of lesion were documented by CT-scans. Deep lesions in the reference sample included basal ganglia and/or thalamus and/or internal capsule and/or external capsule and/or insula. This cumulative localisation did not allow us to separate cases of deep lesion with or without involvement of the deep nuclei; however, the cerebral cortex was always spared. As a result, the number of deeply damaged patients may have been overestimated in the reference sample. We decided to accept this bias, as it acts against the hypothesis under test. Lesions sparing all of the above structures were defined as 'cortical', even if, strictly speaking, they also involved a certain amount of the underlying white matter. In the standard aphasic sample, the 'cortical lesioned' group also included patients with a single lesion in the white matter of a specific lobe. Similar crossed aphasic patients (numbers 5 and 34 in Table II) with a lesion confined to the white matter underlying the supramarginal gyrus or a periventricular lesion, were included in the cortical group. The incidence of haemorrhage was $15 \%$ in the standard sample and $21.6 \%$ in the crossed sample, a discrepancy far from statistical significance (Chi-square $=1.09$, D.F. $=1, p$ $=$ N.S.).

In this sample, it appears that pure deep lesions were more common in the crossed aphasic group: $25.0 \%$ versus $7.0 \%$.

The incidence of deep lesions in the standard aphasic population can also be estimated from other sources. Thus, as a check on the reliability of our figures, we considered the recent survey of 221 cases by Willmes and Poeck (1993). In this series of patients (see their Table 1) there was a rate of deep lesions of $14.9 \%$. This is a higher figure than that estimated from the Milan sample. However, some of the deep cases from the Willmes and Poeck series also had cortical damage (see their Table 3), whereas mixed cases were not considered 'deep' in either the Milan sample or the crossed group. Therefore, the rate of pure deep lesions observed in the Willmes and Poeck series is likely to be smaller than $14.9 \%$ (however, it should be recalled that among crossed aphasics, the incidence of pure deep lesions was $25.0 \%$ ). Notwithstanding this overestimation of pure deep lesions in standard aphasics, we decided to collapse the German and Milan series of standard aphasics; the resultant incidence of purely deep standard aphasics was $10.4 \%$. The comparison with the crossed group (see Table III) yielded a significant Chi-square (7.064, D.F. $=1$, $p=0.008)$.

TABLE III. Prevalence of standard and crossed aphasics according to the lesion site in different samples.

\begin{tabular}{lcc}
\hline & $\begin{array}{c}\text { Standard aphasics } \\
\text { (Laiacona, 1985 }+ \\
\text { Willmes and Poeck, } \\
\text { 1993): } n=508\end{array}$ & $\begin{array}{c}\text { Crossed aphasics } \\
\text { (overall) } n=36\end{array}$ \\
\hline $\begin{array}{l}\text { Cortical lesions } \\
\text { Cortical and deep }\end{array}$ & $263(51.8 \%)$ & $19(52.78 \%)$ \\
nuclei lesions & $192(37.8 \%)$ & $8(22.2 \%)$ \\
Purely deep lesions & $53(10.4 \%)$ & $9(25.00 \%)$
\end{tabular}

For a comment about the patients' classification made by Willmes and Poeck, 1993, see text.

The prevalence of deep lesions with or without a cortical lesion was not higher in crossed aphasic than in standard aphasics $(47.22 \%$ versus $48.23 \%$; Chisquare $<1$, N.S.): This finding casts doubt on Habib et al.'s (1983) hypothesis that implies a greater representation of deep lesions, irrespective of the presence of associated cortical damage.

\section{DISCUSSION}

Habib et al. (1983) have suggested that aphasia is seen more often following a right deep lesion than a right cortical lesion because subcortical structures, of an earlier philogenetic origin, are systematically 'less lateralised'. However, their hypothesis is loosely defined and seems to suggest that not only purely deep lesions, but also mixed lesions (cortical and deep) are overrepresented in crossed aphasics. In our survey, deep lesions (with and without cortical involvement) were not overrepresented in crossed aphasics whereas only pure deep lesions were.

To account for the higher incidence of purely deep lesions among crossed aphasics, we have an alternative hypothesis. The figures we have analysed so far were drawn from samples selected for the presence of aphasia. Let us consider the case of standard, lefthemisphere damaged patients: it is well known that a certain percentage of patients with purely deep lesions are not included within samples selected for aphasia, on the grounds that they show no language 
disturbances (see e.g. Cappa et al., 1983, 1986). As a result, the percentage of patients with purely deep lesions is smaller when subjects are sampled for aphasia than when they are sampled for brain lesions. Unfortunately, satisfactory samples of the latter type are not available from the literature.

Let us now consider crossed aphasics. Here again, our focus is on subjects selected for the presence of aphasia. As for standard aphasics, the percentage of purely deep lesions is influenced by the rate at which patients slip through the sampling net because their language is unaffected. One possible explanation for the overrepresentation of purely deep lesions among crossed aphasics is that fewer subjects with crossed language representation are free from aphasia after a purely deep lesion. In other words, the right hemisphere of subjects with crossed language representation could be equally liable to aphasia either due to cortical or deep lesions, whereas among subjects with standard representation, deep structures are less often necessary to ensure language functions.

Among crossed aphasics it seems feasible that the concentration of both language and attentional functions within one hemisphere (and the consequent sharing of neural resources) would make these functions more fragile. The effect could be a greater incidence of aphasia after purely deep lesions only in anomalous dextral subjects, with language and attention 'crowded' in the right hemisphere.

In this respect, it is of interest to group the crossed aphasics described in the literature according to the presence or absence of unilateral neglect (Table IV).

In our review of 36 crossed aphasics (Table II), purely deep lesions were present in seven of the eighteen patients with Unilateral Neglect (38.9\%), whereas in the other eighteen patients without Neglect, deep lesions were present in only two $(11.1 \%)$. The analysis of the resultant contingency table is shown in Table IV. The degrees of freedom were split accord- ing to the method of Kimball (Maxwell, 1961). The proportion of deep lesions was greater in crossed aphasics, but varied according to the presence of Unilateral Neglect. The incidence of deep lesions in crossed aphasics without Unilateral Neglect was similar to that of standard aphasics, whereas it was higher in crossed aphasics with Unilateral Neglect. An interference between language and visuo-attentional mechanisms, represented in the same hemisphere in the case of cross-lateralisation of language, and a possible forced sharing of neural resources could explain the greater vulnerability of language after a purely deep lesion in these cases. The topic of right hemisphere crowding has been discussed so far with reference to early unilateral damage to the left hemisphere that causes a right language representation. In these cases there is a greater vulnerability for those capacities that normally depend on the right hemisphere (Teuber, 1974; Milner, 1974). In our case we hypothesise that right deep structures are crucial for language and visual attention when the latter functions are both subserved by the right hemisphere. This suggests a peculiarity of the intrahemispheric reorganisation of the right hemisphere, possibly on the basis of a more diffuse representation of functions, as suggested by Strauss et al. (1990). As can be appreciated from an inspection of Table IV, crossed aphasia can be observed also without the concomitance of Unilateral Neglect and the literature reports cases of 'pure' crossed aphasia without other symptoms normally associated with right hemisphere lesions (e.g. Marshall and Halligan, 1992). Functional overcrowding of the right hemisphere is by no means necessary for the appearance of crossed aphasia. However, the lack of evidence of visuo-perceptual deficits and of Unilateral Neglect in crossed aphasics may derive from different sources. Either the functional localisation is completely crossed, and all the functions normally represented on the right side are

TABLE IV. Analysis of the relationship between lesion site, hemispheric language representation and Unilateral Neglect

\begin{tabular}{lccc}
\hline & $\begin{array}{c}\text { Crossed aphasics with } \\
\text { Unilateral Neglect: } \\
n=18\end{array}$ & $\begin{array}{c}\text { Crossed aphasics } \\
\text { without Unilateral Neglect: } \\
n=18\end{array}$ & $\begin{array}{c}\text { Standard aphasics } \\
\text { (Laiacona, 1985 + Willmes } \\
\text { and Poeck, 1993): } n=508\end{array}$ \\
\hline Cortical lesions & $7(38.9 \%)$ & $12(66.7 \%)$ & $263(51.8 \%)$ \\
Cortical and deep nuclei lesions & $4(22.2 \%)$ & $4(22.2 \%)$ & $192(37.8 \%)$ \\
Purely deep lesions & $7(38.9 \%)$ & $2(11.1 \%)$ & $53(10.4 \%)$ \\
\hline
\end{tabular}

Overall Chi-square $=15.916$, D.F. $=4, p=0.003$.

Partition of degrees of freedom: Within crossed aphasics: interaction between lesion site (cortical versus cortical and deep) and presence of Unilateral Neglect: Chi-square $=0.556$, D.F. $=1$, N.S. Between crossed and standard aphasics: is there a different proportion of cortical lesions versus cortical and deep-lesions? Chi-square $=1.419$, D.F. $=1$, N.S. Within crossed aphasics: is the proportion of purely deep lesions greater when patients are affected by Unilateral Neglect? Chisquare $=6.877$, D.F. $=1, p=0.009$. Between crossed and standard aphasics: is the proportion of purely deep lesions greater among crossed aphasics? Chi-square $=7.064$, D.F. $=1, p=0.008$. 
subserved by the left-hemisphere, or these functions are still right-sided, but their neural substrate was spared by the lesion. In the individual patient only a functional activation study with PET or analogous techniques may provide the answer to such questions. Whereas group studies can estimate the general statistical rules governing the clinico-anatomical correlations, they cannot provide all-or-none rules that are valid for single cases. In every case, should our hypothesis be confirmed, the study of interference between language and attentional functions within the same hemisphere could represent an interesting avenue for future neuropsychological research.

\section{Acknowledgements}

We are indebted to Prof. G. Berlucchi for his comments on an earlier version of this paper. Gillian Jarvis revised the English version of the paper.

\section{REFERENCES}

Alexander MP, Fischette MR and Fischer RS (1989) Crossed aphasias can be mirror image or anomalous. Brain, 112, 953-973.

Angelergues R, Hécaen H, Djindjian R and Jarrié-Hazan N (1962) Un cas d'aphasie croisée (Thrombose de l'artère sylvienne droite chez une droitière). Revue Neurologique, 107, 543.

Assal G (1982) Etude neuropsychologique d'une aphasie croisée avec jargonagraphie. Revue Neurologique, 138, $507-515$.

Assal G (1987) Aphasie croisée chez un enfant. Revue Neurologique, 143, 532-535.

Assal G, Perentes E and Deruaz JP (1981) Crossed aphasia in a right-handed patient. Archives of Neurology, 38, 455-458.

Basso A, Capitani E, Laiacona M and Zanobio ME (1985) Crossed aphasia: one or more syndromes? Cortex, 21, 25-45.

Basso A, Bracchi M, Capitani E, Laiacona M and Zanobio E (1987) Age and evolution of language area functions. A study on adult stroke patients. Cortex, 23, 475-483.

Berndt RS, Mitchum CC and Price TR (1991) Short-term memory and sentence comprehension. An investigation of a patient with crossed aphasia. Brain, 114, 263-280.

Boller F (1973) Destruction of Wernicke's area without language disturbance. Neuropsychologia, 11, 243-246.

Brown JW and Wilson FR (1973) Crossed aphasia in a dextral. A case report. Neurology, 23, 907-911.

Brust JCM, Plank C, Burke A, Guobadia MMI and Healton EB (1982) Language disorder in a right-hander after occlusion of the right anterior cerebral artery. Neurology, 32, 492-497.

Cappa SF, Cavallotti G, Guidotti M, Papagno C and Vignolo LA (1983) Subcortical aphasia: two clinical-CT scan correlation studies. Cortex, 19, 227-241.

Cappa SF, Papagno C, Vallar G and Vignolo LA (1986) Aphasia does not always folow left thalamic hemorrage: a study of five negative cases. Cortex, 22, 639-647.
Cappa SF, Perani D, Bressi S, Paulesu E, Franceschi M and Fazio F (1993) Crossed aphasia: a PET follow-up study of two cases. Journal of Neurology, Neurosurgery and Psychiatry, 56, 665-671.

Carr MS, Jacobson T and Boller F (1981) Crossed aphasia: analysis of four cases. Brain and Language, 14, 190-202.

Castro-Caldas A, Confraria A, Paiva T and Trindade A (1986) Contrecoup injury in the diagnosis of crossed aphasia. Journal of Clinical and Experimental Neuropsychology, 8, 697-701.

Castro-Caldas A, Confraria A and Poppe P (1987) Non-verbal disturbances in crossed aphasia. Aphasiology, 1, 403-413.

Cohen I, Hermine O, Gray F and Degos JD (1993) Crossed aphasia with visceral situs inversus. Annals of Neurology, 33, 215-218.

Colombo A, Guerzoni MC, Miscio G and Panzetti P (1984) Lafasia crociata: considerazioni su un caso clinico. Rivista di Patologie Nervose e Mentali, 105, 67-74.

Delreux V, de Partz MP, Kevers L and Callewaert A (1989) Aphasie croisée chez un droitier. Revue Neurologique, 145, 725-728.

Demeurisse G, Hublet G, Coekaerts MJ, Derouck M and Capon A (1986) Assessment of hemispheric dominance for language in crossed aphasia by two atraumatic methods. Cortex, 22, 305-311.

Denes $G$ and Caviezel F (1981) Dichotic listening in crossed aphasia. 'Paradoxical' ipsilateral suppression. Archives of Neurology, 38, 182-185.

Faglia L and Vignolo LA (1990) A case of "crossed aphasia" in which the integrity of the left hemisphere is assessed by MRI. Italian Journal of Neurological Sciences, 11, 51-55.

Fernandez-Martìn F, Martìnez-Lage JM, Madoz P and Maravi E (1968) La afasia cruzada. Estudio clinico con comprobaciòn anatòmica de un caso. Journal of the Neurological Sciences, 7, 565-570.

Fournet F, Virat-Brassaud ME, Guard O, Dumas R, Auplat $\mathrm{Ph}$ and Marchal G (1987) Alexie-agraphie croisée chez un droitier. Revue Neurologique, 143, 214-219.

Fromm D, Holland AL, Swindell CS and Reinmuth OM (1985) Various consequences of subcortical stroke. Prospective study of 16 consecutive cases. Archives of Neurology, 42, 943-950.

Giovagnoli AR (1993) Crossed aphasia. Report of a rare case in a glioblastoma patient. Italian Journal of Neurological Sciences, 14, 329-332.

Guard O, Fournet F, Sautreaux JL and Dumas R (1983) Troubles du language au cours d'une lesion frontale droite chez un droitier. Incohérence du discours et paraphasies 'extravagantes'. Etude neuropsychologique. Revue Neurologique, 139, 45-53.

Haaland KY and Miranda F (1983). Psychometric and CT scan measurements in a case of crossed aphasia in a dextral. Brain and Language , 17, 240-260.

Habib M, Joanette Y, Ali-Cherif A and Poncet, M (1983) Crossed aphasia in dextrals: a case report with special reference to site of lesion. Neuropsychologia, 21, 413-418.

Hadar U, Ticehurst S and Wade JP (1991) Crossed anomic aphasia: mild naming deficits following right brain damage in a dextral patient. Cortex, 27, 459-468. 
Hamasaki T, Suzuki K, Hirakawa K, Imahori Y and Nakajima S (1987) Japanese case of crossed aphasia in a right-handed patient. A propos of kana and kanji. Revue Neurologique, 143, 47-54.

Henderson VW (1983) Speech fluency in crossed aphasia. Brain, 106, 837-857.

Henderson VW, Oken B and Alexander MP (1981) Fluent crossed aphasia with crossed Gerstmann syndrome in a right-handed man. Annals of Neurology, 10, 102.

Hindson DA, Westmoreland DE, Carroll WA and Bodmer BA (1984) Persistent Broca's aphasia after right cerebral infarction in a right-hander. Neurology, 34, 387-389.

$\mathrm{Hu}$ YH, Qiou YG and Zhang GQ (1990) Crossed aphasia in Chinese: a clinical survey. Brain and Language, 39, 347-356.

Joanette Y, Puel M, Nespoulous JL, Rascol A and Lecours AR (1982) Aphasie croisée chez les droitiers. I. Revue de la littérature. Revue Neurologique, 138, 575-586.

Kapur N and Dunkley B (1984) Neuropsychological analysis of a case of crossed dysphasia verified at postmortem. Brain and Language, 23, 134-147.

Karant P and Rangamani GN (1988) Crossed aphasia in a multilingual. Brain and Language, 34, 169-180.

Laiacona M (1985) Evoluzione anatomo-funzionale delle aree del linguaggio nell'età adulta. Studio clinicotomodensitometrico. Tesi di specialità in Neurologia (Post-doctoral Dissertation), University of Pavia.

Larrabee GJ, Kane RL and Rodgers JA (1982) Neuropsychological analysis of a case of crossed aphasia: implications for reversed laterality. Journal of Clinical Neuropsychology, 4, 131-142.

Loring DW, Meador KJ, Lee GP, Murro AM, Smith JR, Flanigin HF, Gallagher BB and King D (1990) Cerebral language lateralization: evidence from intracarotid amobarbital testing. Neuropsychologia, 28, 831-838.

Marshall JC and Halligan PW (1992) Crossed aphasia in a dextral without minor hemisphere signs. Behavioural Neurology, 5, 247-250.

Martins IP, Ferro JM and Trindade A (1987) Acquired crossed aphasia in a child. Developmental Medicine and Child Neurology, 29, 96-100.

Maxwell AE (1961) Analysing Qualitative Data. Methuen, London.

Milner B (1974) Hemispheric specialisation: scope and limits. In: The Neurosciences: Third Study Program (Eds FO Schmitt and FG Worden) pp.75-89, MIT press, Cambridge, MA.

Paradis M and Goldblum MC (1989) Selective crossed aphasia in a trilingual aphasic patient followed by reciprocal antagonism. Brain and Language, 36, 62-75.

Perani D, Papagno C, Cappa S, Gerundini P and Fazio F (1988) Crossed aphasia: Functional studies with single photon emission computerized tomography. Cortex, 24, 171-178.
Pillon B, Desi M and Lhermitte F (1979) Deux cas d'aphasie croisée avec jargonagraphie chez des droitiers. Revue Neurologique, 135, 15-30.

Primavera A and Bandini F (1993) Crossed aphasia: analysis of a case with special reference to the nature of the lesion. European Neurology, 33, 340-33.

Puel M, Joanette Y, Levrat M, Nespoulous JL, Viala MF, Lecours AR and Rascol A (1982) Aphasie croisée chez les droitiers. II. Etude neurolinguistique et neuropsychologique d'un cas. Evolution sur deux ans. Revue Neurologique, 138, 587-600.

Reinvang I (1987) Crossed aphasia and apraxia in an artist. Aphasiology, 1, 423-434.

Roeltgen DP and Heilman KM (1983) Apractic agraphia in a patient with normal praxis. Brain and Language, 18, $35-46$.

Sakurai Y, Kurisaki H, Takeda K, Iwata M, Bandoh M, Watanabe T and Momose T (1992) Japanese crossed Wernicke's aphasia. Neurology, 42, 144-148.

Schweiger A, Wechsler AF and Mazziotta JC (1987) Metabolic correlates of linguistic functions in a patient with crossed aphasia: a case study. Aphasiology, 1, 415-421.

Solin D (1989) The systematic misrepresentation of bilingual-crossed aphasia data and its consequences. Brain and Language, 36, 92-116.

Strauss E, Satz P and Wada J (1990) An examination of the crowding hypothesis in epileptic patients who have undergone the carotid amytal test. Neuropsychologia, 28, 1221-1227.

Sweet EWS, Panis W and Levine DN (1984) Crossed Wernicke's aphasia. Neurology, 34, 475-479.

Teuber HL (1974) Why two brains? In: The Neurosciences: Third Study Program Eds FO Schmitt and FG Worden (pp.71-74). MIT press, Cambridge, MA.

Urbain E, Seron X, Remits A, Cobben A, Van der Linden M and Mouchette R (1978) Aphasie croisée chez une droitière. A propos d'une observation. Revue Neurologique, 134, 751-759.

Walker-Batson D, Wendt JS, Devons MD Sr, Barton MM and Bonte FJ (1988) A long-term follow-up case study of crossed aphasia assessed by single-photon emission tomography (SPECT), language and neurospychological testing. Brain and Language, 33, 311-322.

Washimi Y, Makishita H, Miyasaka M, Fujita T and Yanagisawa N (1987) Crossed aphasia with jargonagraphia due to right putaminal hemorrage. A study by 133Xe single photon emission (CT). Rinsho Shinkeigaku, 27, 12-8.

Willmes K and Poeck K (1993) To what extent can aphasic syndromes be localized? Brain, 116, 1527-1540. 


\section{APPENDIX}

Fresh cases of crossed aphasia reported in the literature by Joanette et al. (1982) until May 1994, not present in our list grouped for the reason of exclusion.

Absence of true aphasia or only transitory symptoms:

Guard et al. 1983

Perani et al. 1988; N.1.

Lack of CT scan:

${ }^{1}$ Angelergues et al. 1962

${ }^{1}$ Fernandez-Martìn et al. 1968 (excluded also for the non-vascular aetiology and for his pre-surgical examination).

${ }^{1}$ Brown and Wilson, 1973

Henderson et al. 1981 (excluded also for the lack of anamnestic and clinical data).

Non-vascular aetiology:

Larrabee et al. 1982

Castro-Caldas et al. 1986

Giovagnoli, 1993

Primavera and Bandini, 1993

Presence of lesion on the left side:

Alexander et al. 1989; N.2

Sweet et al. 1984

Presence of other neurological disorders:

Loring et al. 1990

Hadar et al. 1991

Too poorly educated:

Roeltgen and Heilman, 1983

Fromm et al. 1985 N.9 (excluded also for a small older lesion affecting the left occipital lobe).

Castro-Caldas et al. 1987, N.3
Handedness not assessed:

Brust et al. 1982 (excluded also because of his poor language examination).

Presence of familial sinistrality:

Pillon et al. 1979 N.1 and N.2

Assal et al. 1981

Henderson, 1983 N.1

Fournet et al. 1987

Too early examination (less than two weeks) or longterm follow-up:

Fromm et al. 1985, N.8 (excluded also for transitory symptoms).

Castro-Caldas et al. 1987, N.4

Walker-Batson et al. 1988

Speakers languages written in non-alphabetic script:

Washimi et al. 1987

Hamasaki et al. 1987

Hu et al. 1990

Sakurai et al. 1992

Multilinguism:

Karant and Rangamani, 1988

Solin, 1989

Paradis and Goldblum, 1989 (excluded also for non-vascular aetiology).

Acquired aphasia in children:

Martins et al. 1987

Assal, 1987

${ }^{1}$ Cases included by Joanette et al. (1982) and excluded because they were not CT-documented. 


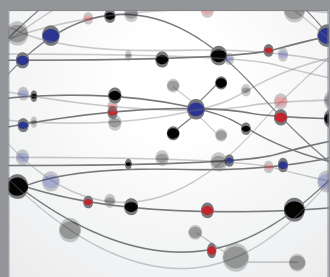

The Scientific World Journal
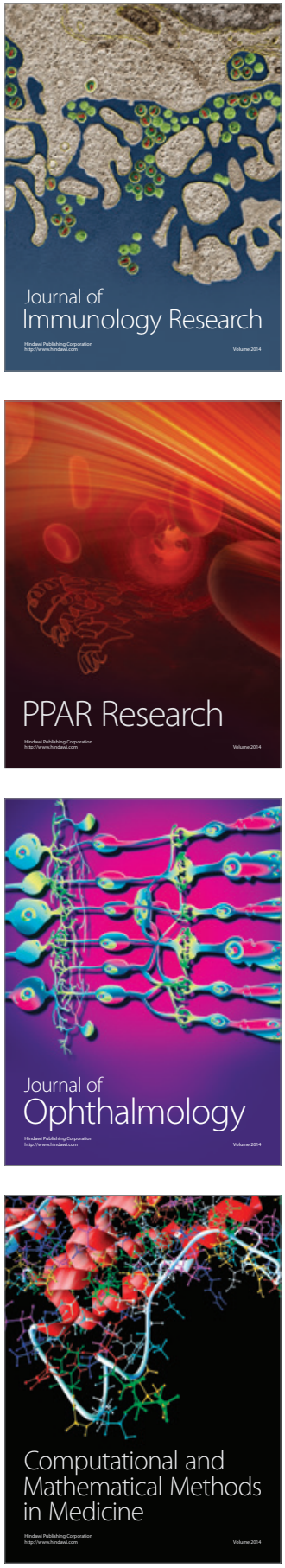

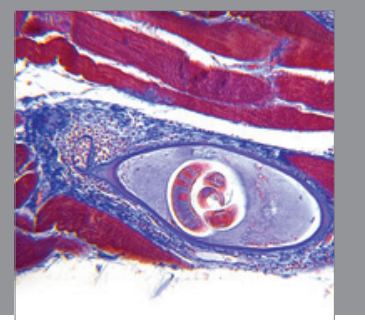

Gastroenterology

Research and Practice
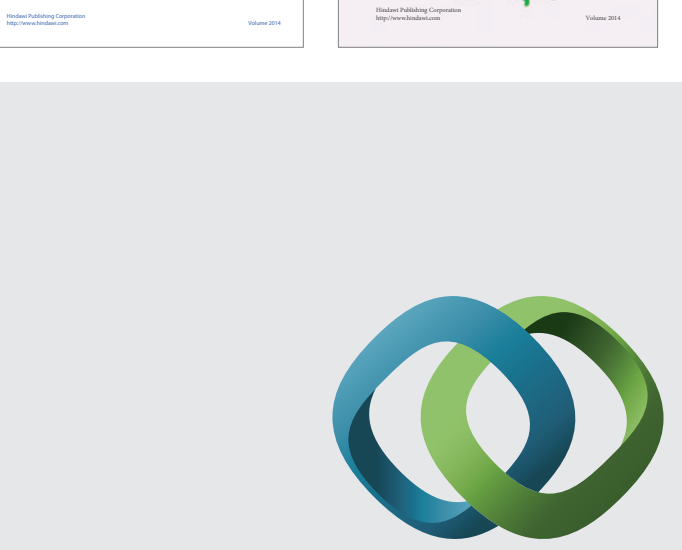

\section{Hindawi}

Submit your manuscripts at

http://www.hindawi.com
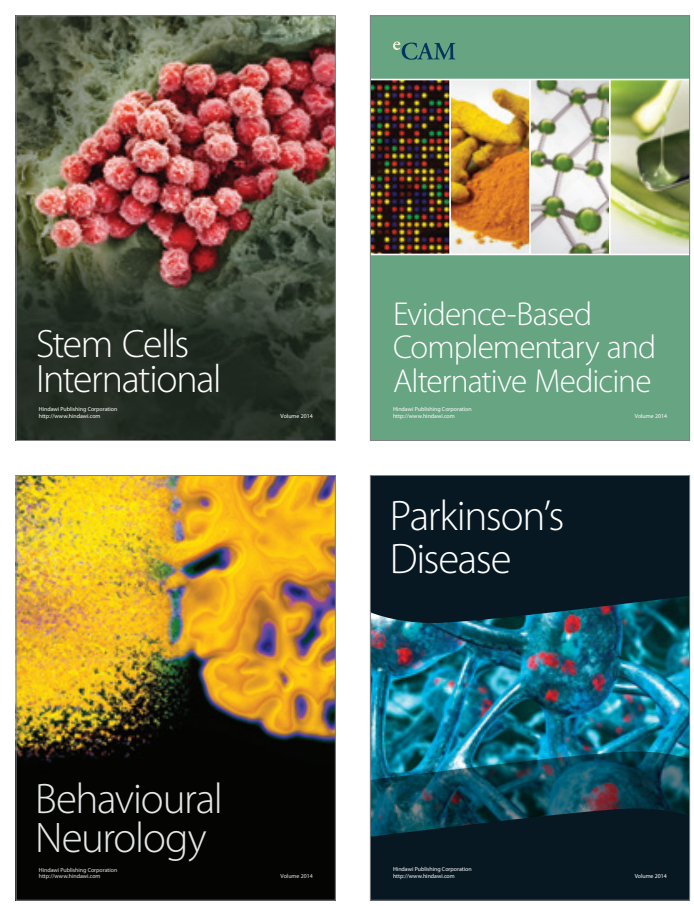

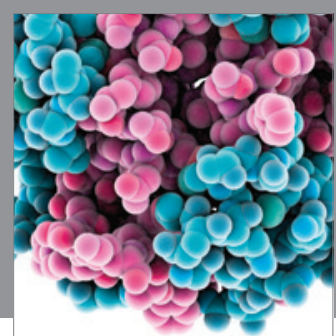

Journal of
Diabetes Research

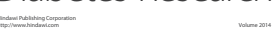

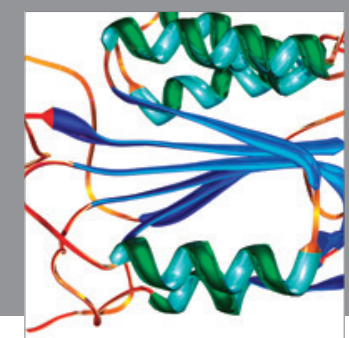

Disease Markers
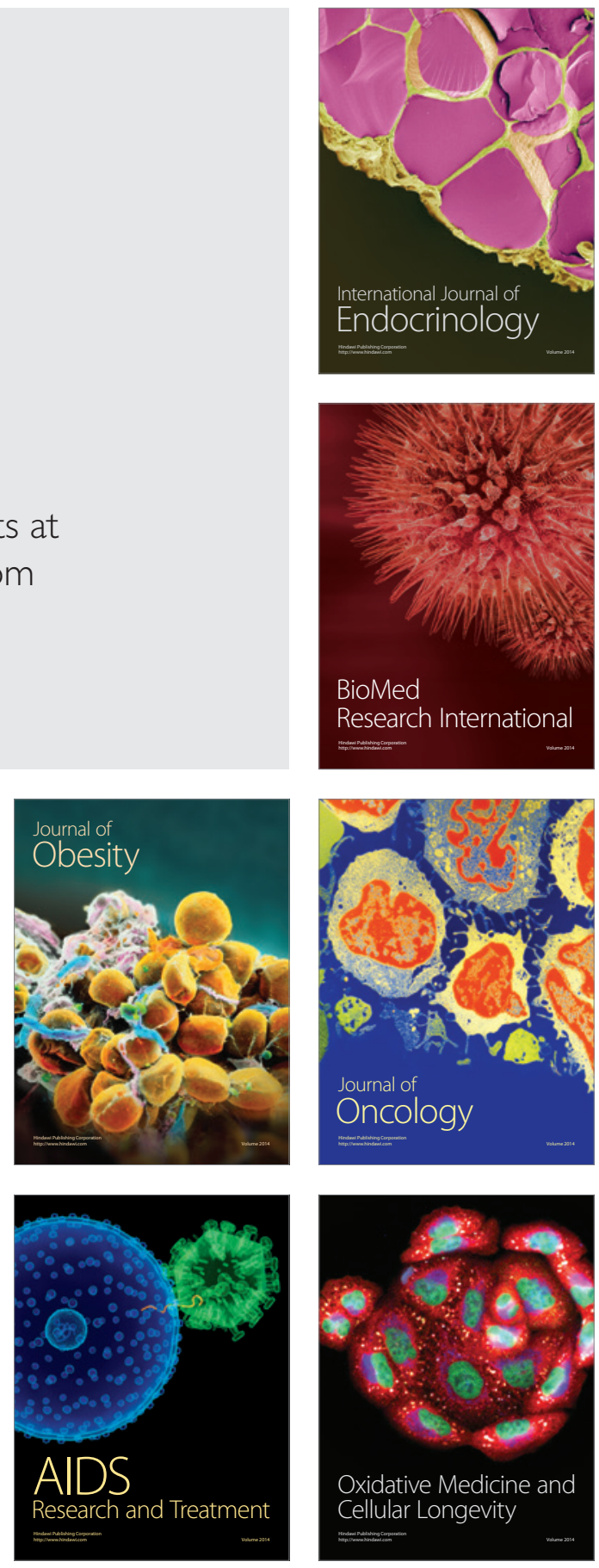